\title{
Silat Pengantin: Seni Pertunjukan Tradisi Melayu di Bentan Penao, Kepulauan Riau
}

\author{
Widyanarto, Doni Febri Hendra, Siguti Aprinnostein \\ Program Studi Seni Tari, Universitas Universal \\ Kompleks Maha Vihara Duta Maitreya Bukit Beruntung, Sungai Panas, Batam \\ Email: widyanarto85@gmail.com
}

\begin{abstract}
The wedding martial in Riau Islands Province is a traditional pencak silat that is part of Malay cultures. In the Kiambang Putih Institute in Bentan Penao, Bintan Regency, a martial art performance presented at a traditional Malay wedding that is also called silat flag. This research used choreography theory approach, based on textual and contextual analysis. Ethnography approach is used by visiting directly to the research field for observing and studying deeply about the performance. The form of presentation is divided into two parts, namely silat flag and silat performance. Silat flag is displayed by two fighters, using the red flag and white color properties. The red and white flags are symbolized to unite two human beings into the family ark. The red flag is interpreted as red blood, which is from the bride. The symbol of the white flag is interpreted as white blood, which is from the groom. The silat flag performance ends with the unification of both flags. It will be continued with silat performance. The silat performance is displayed by one fighter who performed in turn. The pattern of playing his musical instruments is played repeatedly and monotonically, so it looks sanctity.
\end{abstract}

Keywords: bride silat, traditional art performances, Malay customs

\begin{abstract}
ABSTRAK
Silat pengantin di Provinsi Kepulauan Riau merupakan seni pencak silat tradisional yang menjadi bagian dari budaya Melayu. Di Perguruan Kiambang Putih di Bentan Penao, Kabupaten Bintan, pertunjukan seni silat disajikan di acara pernikahan adat Melayu, yang disebut juga dengan istilah silat bendera. Penelitian ini menggunakan pendekatan teori koreografi, dengan kajian tekstual dan kontekstual. Pendekatan etnografi digunakan peneliti dengan terjun langsung ke lapangan untuk mengamati, mempelajari, dan mengkaji lebih dalam mengenai kesenian tersebut. Bentuk penyajiannya terbagi menjadi dua bagian, yaitu silat bendera dan silat persembahan. Silat bendera ditampilkan oleh dua orang pesilat, dengan menggunakan properti bendera warna merah dan warna putih. Simbol bendera berwarna merah dan putih memiliki makna untuk mempersatukan dua insan manusia ke dalam bahtera keluarga. Bendera merah dimaknai sebagai darah merah, dalam hal ini dari mempelai wanita. Simbol bendera putih dimaknai sebagai darah putih, dalam hal ini dari mempelai pria. Persembahan Silat bendera diakhiri dengan menyatunya kedua bendera. Kemudian, dilanjutkan dengan silat persembahan, yang ditampilkan oleh satu orang pesilat, yang dilakukan secara bergantian. Pola memainkan instrumen musiknya dimainkan secara berulang-ulang dan monoton sehingga tampak kesakralannya.
\end{abstract}

Kata kunci: silat pengantin, pertunjukan seni tradisi, adat Melayu 


\section{PENDAHULUAN}

Seni pertunjukan tradisi Melayu di wilayah Kepulauan Riau beraneka ragam. Kesenian tradisional itu sendiri sebagai cerminan terhadap budaya setempat. Tari terbentuk dari masyarakat pemiliknya, dan menjadi cerminan bagi lingkungan budaya dan karakteristik kelompok masyarakat asalnya (Restela, 2017: 188). Masyarakat Melayu adalah masyarakat yang dinamis, yang menjunjung tinggi nilai-nilai yang universal, yakni kebenaran, keadilan, dan menghormati perbedaan. Istilah seni pertunjukan dalam budaya Melayu terkadang disamakan dengan sebutan seni persembahan. Makna seni persembahan atau seni pertunjukan sendiri meliputi adanya penampilan seniman seni pertunjukan di tempat tertentu dan melakukan komunikasi secara langsung kepada penonton atau penikmatnya, dengan didasari kepada nilai-nilai budaya yang dianut dan diresapi masyarakat Melayu (Takari, 2014: 27).

Salah satu seni pertunjukan tradisional Melayu di Provinsi Kepulauan Riau yang menjadi objek penelitian ini adalah pertunjukan seni silat Melayu. Pertunjukan seni silat Melayu pada hakekatnya merupakan sebuah pertunjukan tradisi yang berkaitan erat dengan segala konteks kepentingan budaya masyarakat pendukungnya. Awal mula jenis tarian ini masuk dalam kelompok tarian yang bersifat sakral. Pada dasarnya, tarian yang bersifat sakral ini bentuk penyajiannya difungsikan sebagai bagian dari upacara yang berkenaan dengan daur kehidupan, seperti kelahiran, inisiasi pubertas, perkawinan, dan kematian (Hadi, 2005: 19). Dalam acara pernikahan adat istiadat budaya Melayu, pertunjukan seni silat Melayu memiliki peranan yang penting, yaitu menjadi bagian dalam satu kesatuan prosesi bertemunya antara mempelai pria dan wanita. Makna seni persembahan atau seni pertunjukan adalah adanya penampilan seniman seni pertunjukan di tempat ter- tentu dan melakukan komunikasi dengan penonton atau penikmatnya, dengan berdasarkan kepada nilai-nilai budaya yang dianut dan diresapi masyarakat Melayu. Seni silat Melayu semacam ini disebut juga dengan istilah silat pengantin. Silat pengantin di Bentan Penao terdapat dua bagian atau babak, yaitu bagian pertama dinamakan dengan sebutan silat bendera, dan bagian dua dinamakan dengan istilah silat persembahan. Dua bagian silat pengantin ini memiliki bentuk dan makna yang berbeda. Adat istiadat budaya Melayu dalam penyajian pertunjukan seni tradisi pencak silat Melayu masih dipegang sampai saat ini (Wawancara Raja Timat, 58 tahun, 12 Januari 2017).

Pertunjukan tradisi seni silat Melayu terlihat juga dalam tampilan busananya yang menggunakan pakaian adat Melayu. Dialek bahasa yang digunakan untuk berpantun menggunakan syair Melayu, dan pada saat persembahan berlangsung diiringi oleh musik pengiring yang membuat perpaduan antara penampilan gerak silat dengan musiknya semakin indah dan dinamis. Pertunjukan tradisi seni pencak silat Melayu sebagai salah satu bagian dari kesenian yang hidup dan berkembang di lingkungan masyarakat merupakan produk budaya Melayu. Kesenian yang bersifat tradisi pada dasarnya berarti segala sesuatu yang diwarisi dari masa lalu. Tradisi merupakan hasil cipta dan karsa manusia, yang obyek materialnya adalah kepercayaan, khayalan, kejadian atau lembaga yang diwariskan dari satu generasi kegenerasi berikutnya (Murgiyanto, 2004: 2).

Seni pertunjukan tradisi merupakan manifestasi kebudayaan. "Budaya" sendiri berasal dari bahasa Sangsekerta yaitu buddhi, yang berarti akal, pikiran, watak, sedangkan daya, berarti akal, kekuatan. Jadi, budaya artinya himpunan segala usaha untuk memperbaiki sesuatu dengan tujuan mencapai kesempurnaan (Gazalba, 
1967: 35). Penjelasan di atas sebagai bukti bahwa seni pertunjukan tradisional, yang merupakan bagian dari budaya Melayu, masih dipertahankan sampai saat ini, dengan segala keterbatasannya, agar khazanah budaya Melayu tidak punah. Kepunahan suatu bentuk seni pertunjukan bisa jadi disebabkan oleh dua hal, yakni tidak pernah adanya kepedulian akan pengkajian dan pewarisan, dari satu generasi ke generasi berikutnya; atau karena belum tersentuhnya seni pertunjukan oleh industri pariwisata. Seni pertunjukan ini memiliki kesejarahan, nilai filosofi, adat, dan sekaligus memperkuat jati diri masyarakat Melayu. Dengan demikian, melalui khazanah kearifan lokal ini, di kemudian hari, diharapkan kreativitas budaya (cultural creativity) dapat memberikan dampak positif bagi keberhasilan sektor industri pariwisata yang menempatkan peran serta pemerintah, pasar, dan juga masyarakat pemilik budayanya (Hersapandi, 2017: 185).

Berdasarkan uraian yang dikemukakan di atas, rumusan masalah penelitian ini adalah (1) bagaimana peranan seni pertunjukan silat Melayu dalam adat istiadat pernikahan di wilayah Bentan Penao, Kepulauan Riau; dan (2) bagaimana analisis teks dalam penyajian silat Melayu tersebut.

Adapun tujuan penulisan ini adalah untuk mendeskripsikan bentuk penyajian silat pengantin di perguruan Kiambang Putih di Bentan penao, Kabupaten Bintan, Kepulauan Riau, sebagai salah satu khazanah budaya Melayu di wilayah Kepulauan Riau. Selain itu, peneliti juga menganalisis teks yang berkaitan dengan konteks gerak langkah 'bunga silat'. 'Bunga silat' adalah langkah gerak silat yang sudah diperindah guna kepentingan pertunjukan.

\section{METODE}

Penelitianinimenggunakan pendekatan teori koreografi, yaitu kajian tekstual dan kontekstual. Sebuah teks koreografi pada dasarnya merupakan pikiran, gagasan, dan konsep estetik, atau pengetahuan tentang tari secara fisik (teks) yang dapat berdiri sendiri dan dapat dibaca serta dianalisis secara tekstual. Artinya, bahwa analisis tekstual secara empirik hanya dilihat dari aspek luarnya saja atau (surface structure), tidak harus mengkaitkan dengan struktur dalamnya (deep structure) (Hadi, 2007: 23). Pokok-pokok permasalahan penelitian ini akan dipecahkan melalui pendekatan tekstual dan kontekstual. Pendekatan tekstual dititikberatkan pada koreografi seni silat Melayu. Kajian tekstual secara garis besar menganalisis bentuk gerak, teknik gerak, gaya gerak, jumlah penari, jenis kelamin dan postur penari, struktur keruangan, struktur waktu, struktur dramatik, dan tata teknik pentas.

Analisis dilakukan dengan mengupas struktur gerak tari, pola-pola gerak tari, yang pada akhirnya mendapatkan ciri spesifik dan makna yang terkandung dalam gerak langkah 'bunga silat', yang menjadi ciri khas seni pencak silat Melayu Kepulauan Riau. Sebuah koreografi secara fisik (teks) adalah berdiri sendiri, yang dapat dibaca dan dianalisis secara tekstual. Melalui analisis tekstual ini dapat dipahami sebuah bentuk artistik yang bermakna dan berfungsi sebagai identitas budaya suatu masyarakat. Bahkan teks koreografi itu menjadi karakteristik daerah tertentu yang membedakannya dengan daerah lain. Hal ini dikaji secara kontekstual.

Pendekatan etnografi dilakukan dengan terjun langsung ke lapangan untuk mengamati, mempelajari, dan mengkaji lebih dalam menegnai kesenian tersebut. Pengumpulan data dalam penelitian ini dilakukan melalui dua cara. Cara pertama, melakukan kajian di lapangan secara langsung untuk mendapatkan data primer. Cara kedua, melakukan penyelidikan objek di lingkungan masyarakat penggiat perguruan Kiambang Putih untuk mendapatkan data 
sekunder. Kedua cara ini dilakukan dengan observasi partisipasi (participant observation) di perguruan silat Kiambang Putih Bentan Penao. Penulis mengikuti aktivitas secara mandiri di perguruan silat dengan tinggal atau berkomunikasi secara intensif di rumah guru selama hampir tujuh bulan (Januari-Juli 2017) di Bentan Penao, Kepulauan Riau. Selanjutnya, penulis menganalisa beberapa batasan; langkah 'bunga silat' Melayu sebagai elemen gerak dalam persembahan seni silat bendera. Umumnya, silat boleh diikuti oleh siapapun yang berminat. Akan tetapi, dalam ilmu silat sendeng ini tidak hanya sekedar mempelajari secara fisik saja akan tetapi harus memahami ilmu sendeng itu sendiri.

Raja Timat, pimpinan/guru silat sendeng perguruan kiambang putih Bentan Penao, menjelaskan bahwa ilmu sendeng memiliki nilai-nilai filosofis, bagaimana memaknai kehidupan ini. Seperti yang tersirat pada syair bahasa Melayu tua di dalam mempelajari ilmu sendeng sebagai berikut.

Awal salam dengan selawat

Satukan due kalimat syahadat

Tegakkan budaye dengan mufakat

barulah timbul bahase adat

Silat bukan tari

Tapi kate dengan sake

Melayu takakan hilang di bumi

Satukan bangse dengan budaye

Hidup bagaikan mentari pagi

Jelajah alam sampaikan ke senje

Sedetik tidak pernah berhenti di pertengahan garis katulistiwe

Jangan takut dengan mati karne mati suatu keputusan yang tak terduge.

Tapi di sebaliknye takutlah dengan hidup yang penuh bergelimangan

Dengan dose

Berani merah setia biru

Kate dibuat melayu diraje

Berbunyi indah bahase melayu

Satukan bangse dengan budaye

(Wawancara Raja Timat, diijinkan untuk dikutip, 20 Februari 2017)

Terdapat empat kaidah di dalam silat sendeng, antara lain kaidah yang diilhami dari gerakan doa, kaidah yang diilhami dari gerakan qiyam, kaidah yang diilhami dari gerakan rukuk, dan selanjutnya kaidah yang terilhami dari gerakan takbiratul ihram.

Gerak silat sendeng menggunakan langkah empat, yang dapat dipecahkan menjadi sembilan jurus. Antara lain, jurus pertama, berdiri seperti 'alif'. Jurus kedua, terletak pada kata bismilah yang berarti niat dengan makrifat. Jurus ketiga dan keempat adalah lam alif, yang dipahami sebagai langkah lam alif beserta hakekat. Langkah empat dipecahkan lagi menjadi empat jurus. Langkah ini dapat digunakan apabila lawan atau musuh lebih dari satu. Empat jurus ini di antaranya adalah jurus enam, yaitu pukul, jurus tujuh yaitu cekak, jurus delapan yaitu kuntau, dan jurus sembilan yaitu belebat.

Penulis tidak hanya menganalisis objek pertunjukan saja, tetapi mempelajari langkah gerak silat yang selalu hadir dalam sajian pertunjukan dan mengkaji makna di dalamnya. Data yang digunakan untuk mendukung informasi primer yang diperlukan berasal dari sumber tertulis, seperti bukubuku yang berhubungan dengan budaya Melayu, khususnya prosesi adat perkawinan di Kepulauan Riau, informasi yang berasal dari wawancara dengan para seniman, budayawan setempat, serta data berupa dokumentasi pertunjukan silat pengantin di perguruan silat lainnya, seperti silat 'Empat Sahabat', silat Cekak, dan lain-lain.

\section{HASIL DAN PEMBAHASAN}

Konsep seni tradisi Melayu, sebagaimana konsep adat, meliputi bidang kehidupan yang sangat luas. Salah satunya adalah agama, dalam hal ini Islam. Orang Melayu memiliki tradisi sendiri, yang bentuk, corak, dan jenisnya berbeda dengan tradisi agama bukan Melayu.

Dalam hal ini, masyarakat Melayu dalam mengembangkan kebudayaannya dilakukan melalui inovasi dan akulturasi. Kebudayaan Hindu-Budha, Islam, dan Eropa diolah bersama-sama dalam latar budaya 
Melayu sendiri, hingga kebudayaan Melayu memiliki nilai eksotisme dan jati diri (Takari, 2014: 9). Dalam perkawinan menurut adat Melayu, relasi yang terbangun bukan sekadar hubungan antara bujang dan dara (pemuda dan pemudi), akan tetapi merupakan hubungan kekerabatan antara keluarga bujang dan dara (Kadir, 2012: 3). Walaupun setiap daerah di Kepulauan Riau memiliki beragam karakteristik adat budaya, namun di wilayah ini yang dominan adalah suku Melayu.

Setiap wilayah di Kepri mempunyai adat yang hampir sama. Meskipun ditemukan adanya perbedaan, hal ini hampir dapat dipastikan tidak jauh bergeser dari adat dan kebudayaan Melayu di antara wilayah satu dengan wilayah yang lainnya yang ada di provinsi Kepulauan Riau, dalam bentuk variasi dan kreasi. Dengan kata lain, perbedaan itu tidak bersifat substansial.

Prosesi perkawinan adat Melayu diawali dengan upacara pra-pernikahan. Antara lain adalah merisik, meminang, mengantar tanda, mengantar belanja, menjemput, menegakkan bangsal, menggantung, bertangas, berinai curi, berendam, pelaksanaan berendam, mandi berhias, dan hiasan bunga berendam. Prosesi selanjutnya adalah prosesi akad nikah dan tepung tawar. Antara lain adalah akad nikah, tepuk tepung tawar, berinai besar, dan berkhatam Alquran. Selanjutnya, prosesi hari berlangsungnya pernikahan. Di antaranya adalah menjemput pengantin laki-laki, mengarak pengantin laki-laki, silat pengantin, tabur beras kunyit, tali lawe, bersanding, dan makan dengan bersuap. Kemudian, dilanjutkan dengan prosesi setelah hari berlangsung (pernikahan). Di antaranya adalah menyembah orang tua, mandi 'sampat', mandi 'pelepas' ('ketupat lepas'), berkaca dan 'bakar benang tukal', serta menendang kelapa (Kadir, 2012: 72-76).

Dalam prosesi upacara bersanding ini, terbagi ke dalam beberapa tahapan, yaitu prosesi menjemput pengantin laki-laki, prosesi berarak pengantin laki-laki, prosesi buka tali lawe, prosesi silat pengantin, dan diakhiri dengan prosesi bersanding.

Silat pengantin atau lebih dikenal dengan sebutan silat bendera merupakan bagian dari silat sendeng di Bentan Penao. Di dalam bentuk penyajiannya terdapat dua bagian pertunjukan seni silat Melayu, yaitu silat bendera dan silat persembahan.

Silat sendeng berawal dari Bentan Penao, yang terletak di Pulau Bintan, provinsi Kepulauan Riau. Kata 'Penao' sendiri dari kata 'penaung' atau tempat 'bernaung'. Di Bentan Penao terdapat makam panjang, yang nama aslinya tidak diketahui. Karena terdapat di bumi Penao maka disebut 'makam penao'.

Ilmu sendeng dikaji dan dibawakan oleh perguruan Kiambang Putih, Bentan Penao. Misi perguruan ini adalah dimulai dengan salam dengan selawat, kemudian membacakan dua kalimat syahadat, tegakkan musyawarah dan mufakat, serta bahasa adat.

Raja Timat, selaku pelatih silat sendeng, di perguruan Kiambang Putih, dan sekaligus juru kunci makam Penao, menjelaskan bahwa ilmu sendeng memiliki nilai-nilai filosofis mengenai makna kehidupan. Seperti yang tersirat pada syair bahasa Melayu tua di dalam mempelajari ilmu sendeng berikut ini.

Awal salam dengan selawat. Satukan due kalimat syahadat. Tegakkan budaye dengan mufakat. Barulah timbul bahase adat.

Silat bukan tari. Namun kate dengan sake. Melayu tak akan hilang di bumi. Satukan bangse dengan budaye. Hidup bagaikan mentari pagi.

Jelajah alam sampaikan ke senje. Sedetik tidak pernah berhenti di pertengahan garis katulistiwe. Jangan takut dengan mati karne mati suatu keputusan yang tak terduge. Tapi di sebaliknye takutlah dengan hidup yang penuh bergelimangan dengan dose.

Berani merah setia biru. Kate dibuat melayu diraje. Berbunyi indah bahase melayu. Satukan bangse dengan budaye (Wawancara Timat, 22 Februari 2017).

Salah satu bentuk pertunjukan seni silat Melayu adalah silat sendeng yang me- 


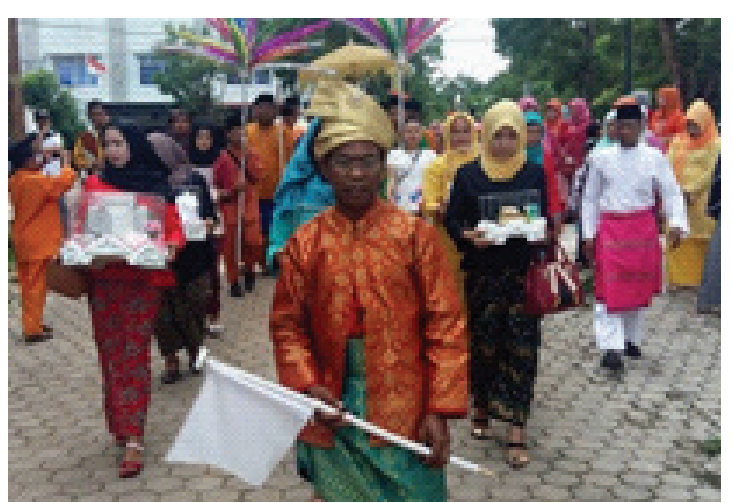

Gambar 1. Pembawa bendera putih pada Prosesi Arak-arakan Pengantin Pria (Sumber: Fahrul Redha, 2017)

miliki peranan dan fungsi yang penting dalam adat Melayu. Perbedaannya, pencak silat umum dengan seni silat Melayu adalah dilihat dari fungsinya. Pencak silat secara umum digunakan untuk menjaga diri/ membela diri, dan sifatnya lebih pada fisik. Sedangkan seni silat Melayu lebih menonjolkan pada langkah bunga seni silat yang memiliki nilai-nilai yang terkandung dalam budaya Melayu. Sifatnya lebih kepada sajian pertunjukan di dalam acaraacara tradisi adat Melayu, di antaranya adalah adat perkawinan. Seni silat Melayu di dalam adat perkawinan wilayah Bentan Penao, dinamakan 'silat bendera'.

Peranan pertunjukan silat bendera di Bentan Penao ini sebagai penghormatan dan pengawalan bertemunya antara mempelai pria dan mempelai wanita yang disimbolkan dengan bendera berwarna merah dan putih (lihat gambar 1). Diawali oleh pesilat yang membawa bendera berwarna putih mengawal mempelai pria di dalam prosesi arak-arakan, sedangkan bendera merah mengawal mempelai wanita. Pertunjukan ini diakhiri dengan bertemunya antara bendera merah dan putih (lihat gambar 2).

Simbol bendera berwarna merah dan putih memiliki makna untuk mempersatukan dua insan manusia ke dalam bahtera keluarga. Bendera merah dimaknai sebagai darah merah, dalam hal ini darah dari mempelai wanita. Simbol bendera putih

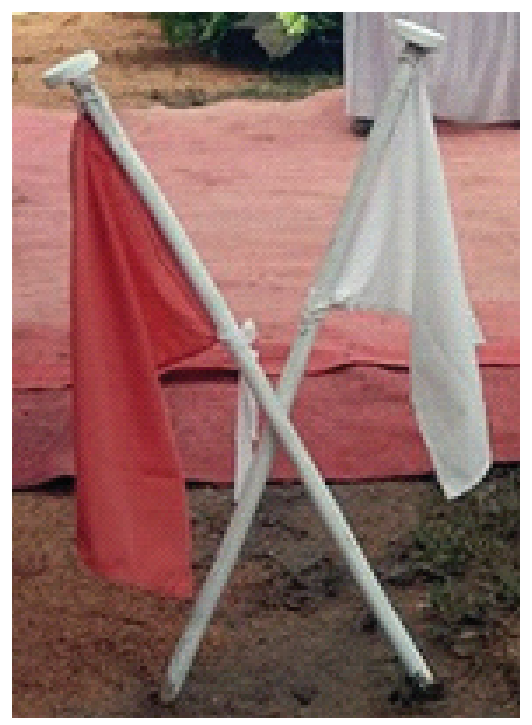

Gambar 2. Bendera Merah Putih, Silat Bendera/ Silat Pengantin Bentan Penao (Sumber: Widyanarto, 2017)

dimaknai sebagai darah putih, dalam hal ini darah dari mempelai laki-laki. Dengan demikian, keberadaan untuk memainkan bendera merah dan putih oleh pesilat ini sebagai gambaran kehidupan dua insan manusia yang saling berinteraksi dalam ikatan tali suci dalam satu kehidupan yang saling berkaitan. Selanjutnya, ditampilkan silat persembahan oleh pesilat untuk memberikan penghormatan mempelai laki-laki sebagai raja sehari. Penyajian silat bendera dipentaskan dengan durasi waktu sekitar kurang lebih tujuh menit (lihat gambar 3).

\section{Bentuk Koreografi Silat Pengantin (Silat Bendera) Bentan Penao}

Koreografi berasal dari kata yunani choreia yang berarti tari massal atau tari kelompok, dan kata grapho yang berarti catatan, yang berarti cataan tari massal atau kelompok. Sedangkan koreografi sebagai pengertian konsep, adalah proses perencanaan, penyeleksian, sampai kepada pembentukan (forming) gerak tari dengan maksud dan tujuan tertentu (Hadi, 2012: 1). Di dalam bentuk penyajian seni silat Melayu, silat bendera Bentan Penao terbagi menjadi dua bagian. Bagian pertama 


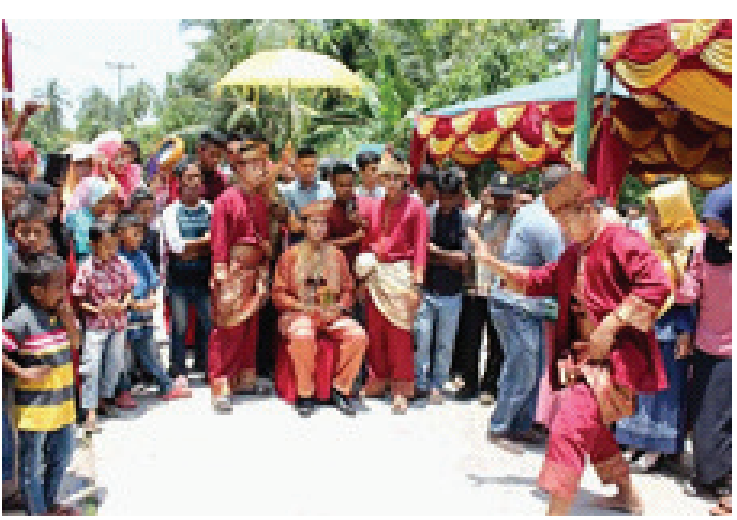

Gambar 3. Sajian Silat Persembahan/Pengantin dalam Upacara Adat Pernikahan Melayu

(Sumber: Irwansyah, 2017)

adalah sajian silat bendera, dan bagian kedua adalah sajian silat persembahan. Bentuk koreografi seni silat Bendera secara sistematik dibedah dengan melihat analisis bentuk gerak, teknik gerak, gaya gerak, jumlah pesilat, analisis jenis kelamin dan postur tubuh, analisis struktur keruangan, struktur waktu, struktur dramatik, analisis tata teknik pentas yang mencakup tata cahaya dan tata rias busana.

Pemahaman koreografi sebagai teks, bersifat deskriptif atau tampak sebagai bentuk luarnya, misalnya melihat bentuk tari dari struktur tarinya (Hadi, 2016: 38-39). Bentuk koreografi sajian silat bendera dalam kajian tekstualnya, mengupas tentang analisis bentuk gerak, teknik, dan gaya. Artinya, bahwa analisis koreografi adalah sesuatu yang tampak, dapat dibaca dan dianalisis secara tekstual, sehingga susunan gerak tari itu secara detail dan rinci dapat dilihat secara kasat mata untuk dapat dikomunikasikan kepada penonton. Selain ketiga analisis tersebut, analisis koreografi juga akan melihat dari segi analisis jumlah penari, analisis jenis kelamin dan postur tubuh, analisis struktur ruang, analisis struktur waktu, analisis struktur dramatik, dan analisis tata teknik pentas. Sedangkan dalam analisis teks terdapat penjelasan konteksnya, karena satu sama lainnya saling terkait.

\section{Analisis Bentuk Gerak}

Gerak sebagai elemen dasar dari tari memiliki peranan penting dalam mengomposisikan maksud sebuah garapan kepada penonton. Gerak tubuh memiliki tiga buah aspek: terjadi dalam ruang, membutuhkan waktu, dan membutuhkan ruang. Ketiga elemen gerak tari ini juga selalu merupakan indikasi emosi dan perasaan (Murgiyanto, 2004). Gerak langkah empat dan langkah delapan merupakan langkah awal dari pengembangan langkah 'bunga silat' yang ditampilkan pada pertunjukan seni tradisi silat Melayu.

Langkah dasar gerak oleh para pesilat sendeng sendiri harus dapat dikuasai dengan baik dan benar. Tidak hanya menguasai secara bentuk dan tekniknya saja, tetapi makna yang tersirat dalam gerak langkah 'bunga silat' tersebut, para pesilat pun harus dapat mengetahuinya juga. Langkah silat empat dan delapan dalam ilmu sendeng ini ditampilkan di langkah 'bunga silat' bendera maupun silat persembahan.

Langkah bunga adalah sebutan gerak silat yang dipertunjukkan silat pengantin, yang digerakkan secara tiba-tiba karena kebiasaan penyaji dalam mengembangkan langkah silat. Dalam istilah tari, hal itu disebut gerak improvisasi. Improvisasi ditandai dengan gerak spontanitas, walaupun gerak-gerak tertentu muncul dari gerak-gerak yang pernah dipelajari atau ditemukan sebelumnya, atau ciri-ciri spontanitas menandai hadirnya improvisasi (Hawkins, 1990: 69-70).

Improvisasi memacu kreativitas dan memberi kesadaran bahwa gerak itu bersifat ekspresif. Improvisasi dapat tumbuh dari gerak-gerak tertentu yang telah dipelajari. Langkah ini biasanya lebih sering digunakan sebagai dasar gerak seni silat Melayu yang biasanya sering disebut dengan langkah bunga.

Adapun gerak yang umum digunakan dalam mengembangkan langkah bunga di 
silat sendeng Bentan Penao di dalam silat bendera adalah langkah sembah, langkah kuntao, dan langkah cekak. Gerakan-gerakan yang hadir tersebut biasanya digunakan sebagai dasar langkah bunga yang diperhalus dengan menghadirkan dari rasa gerak itu sendiri. Jurus silat pada langkah bunga di dalam seni silat Melayu disebut dengan istilah lian.

Kesatuan bentuk penyajiannya terbagi menjadi dua bagian. Yang pertama adalah silat bendera dan bagian kedua dilanjutkan dengan silat persembahan. Kedua bagian atau babak dalam penyajian silat bendera ini memiliki bentuk dan fungsi yang berbeda. Kedua bagian ini menjadi satu kesatuan yang saling terkait. Berikut ini penjelasan bentuk silat bendera dan silat persembahan di dalam sajian seni silat dalam upacara pernikahan adat Melayu Bentan Penao.

Penyajian silat bendera Bentan Penao ditampilkan oleh dua orang pesilat, dengan membawa bendera merah putih. Satu orang membawa bendera merah dan satu orang membawa bendera putih. Bendera putih dibawa oleh pesilat mewakili pengantin pria yang ditampilkan dalam arak-arakan terlebih dahulu. Tahapan pertama, prosesi buka pintu yang pertama dengan berbalas pantun dan diakhiri dengan disimbolkan memberi uang seikhlasnya yang diletakkan di tempat yang berisi beras putih. Selanjutnya, ditampilkan sajian silat bendera dengan diawali pesilat yang membawa bendera putih ditancapkan di area terbuka bersanding dengan bendera merah. Penyajian silat persembahan Bentan Penao dalam acara pernikahan ditampilkan setelah berakhirnya sajian silat bendera. Di dalam penyajian silat persembahan ditampilkan satu per satu pesilat yang ada. Jumlah pesilatnya tidak ada ketentuan baku berapa jumlahnya, tetapi pada umumnya lebih dari lima orang, diawali dengan melangkah ke tengah panggung, menghadap dengan sikap salam hormat oleh Raja Sahari (pengantin pria).
Variasi gerak merupakan prinsip bentuk yang harus ada dalam sebuah tarian atau koreografi. Dalam proses penyusunan motif-motif gerak, kalimat gerak tari atau koreografi perlu dilakukan variasi. Aspekaspek dalam variasi, yaitu gerak, ruang, dan waktu. Dalam bentuk tari atau koreografi yang baik, semua kepentingan termasuk variasi, harus tertuju pada kesatuan yang utuh (Hadi, 2007: 26).

Sikap sembah ini mengalami pengulangan ruang level (gerak sembah dilakukan dengan sikap berdiri dan duduk), tergantung pesilat yang menggerakkannya. Hal ini disebabkan tidak adanya peraturan baku harus berdiri atau duduk pada saat pertunjukan berlangsung. Sikap sembah dalam silat ditampilkan pada saat mengawali dan mengakhiri pertunjukan.

Selanjutnya, berjabat tangan antara pesilat dengan pengantin pria atau raja sehari, sebagai tanda bahwa pertunjukan silat mendapat restu dan diijinkan untuk melakukan gerak langkah bunga di depan raja sehari, yang disebut gerak kelit. Gerak kelit ini mengalami proses pengulangan variasi gerak. Antara lain, gerak tempo cepat dan biasa, bertenaga dan tidak, dan pengulangan gerak kelit dengan posisi level yang bervareasi antara pesilat satu dengan yang lainnya, antara lain sikap kelit dengan level biasa dan level rendah. Gerak kelit umumnya untuk sikap ancang-ancang, siap sedia, dan waspada terhadap lawan. Sikap kelit di dalam silat bendera dalam prosesi pernikahan Melayu haruslah tetap menghadap raja sehari, dengan tujuan agar tetap tampak sikap santun dan rasa hormat terhadap raja sehari.

Gerak langkah bunga dalam silat bendera tidak ada gerak yang harus dihafalkan secara baku, baik struktur gerak ataupun ragam dan motif geraknya. Hanya saja, dalam pengolahan gerak langkah bunga yang ditampilkan dalam arena pertunjukan merupakan hasil dari kreativitas para pesi- 
lat. Masing-masing pesilat sudah menguasai dasar gerak silat yang ada (silat sendeng). Di antaranya, pengembangan dari gerak dasar langkah empat dan langkah sembilan yang sesuai dengan gaya pesilat itu sendiri. Umumnya, setiap pesilat mengambil lian sembah, lian kuntao, lian pukul atau lian cekak. Dalam visualisasi langkah bunga yang hadir banyak terjadi pengulangan gerak buka dan tutup kaki. Hal ini dilakukan dengan cara tempo cepat atau tempo pelan dengan bentuk berubah-ubah, dan dengan level yang berbeda-beda. Dalam melakukan langkah 'bunga silat' ini, akan tampak kemampuan dari masing-masing pesilat itu sendiri.

Gerak dalam seni tari berbeda dengan gerak maknawi sehari-hari, gerak dalam seni tari telah mengalami perombakan atau dipindahkan dari yang mentah, diubah bentuk menjadi seni (Hawkins, 2003: 3). Di dalam pertunjukan silat pengantin, yaitu silat bendera dan silat persembahan Bentan Penao seperti pertunjukan seni silat Melayu pada umumnya. Dalam pertunjukannya tidak ada gerakan yang dihafalkan, gerak yang ditampilkan merupakan hasil gerak yang terwujud secara spontan. Namun, dalam menganalisis gerak dapat menggunakan pola langkah pesilatnya. Pola langkah yang ditampilkan oleh pesilat berbeda-beda, umumnya setiap pesilat menggunakan pengulangan secara repetisi atau pengulangan yang sama. Antara lain, pada bagian pertama silat bendera, yaitu menggunakan pola langkah formasi berputar dengan melangkah ke samping kanan, pada hitungan pertama diawali dari kaki kiri disilangkan ke kanan, hitungan dua langkah kaki kanan, hitungan tiga silang kaki kiri, hitungan empat langkah buka kaki kanan, hitungan lima mengalihkan berat badan dari kaki kanan menuju kaki kiri, hitungan enam kaki kanan disilangkan ke samping kaki kiri dan duduk dibawa dengan tidak mengubah posisi kaki, dan selanjutnya hitungan tujuh dan delapan kaki kanan kembali melangkah membuka ke samping kanan. Hitungan satu sampai delapan pada uraian di atas merupakan rangkaian satu motif gerak, dan satu motif gerak dilakukan empat kali pengulangan secara repititif hingga membentuk formasi lingkaran. Selanjutnya, gerakan diakhiri dengan menjadi satunya bendera merah dan putih. Kemudian, pada bagian dua, yaitu gerakan melangkah ke samping kanan dan kiri maju dan mundur atau langkah empat penjuru dengan menghadap raja sahari.

Di dalam pertunjukan silat pengantin pada bagian pertama, yaitu silat bendera perpindahan transisinya ditandai dengan penyatuan bendera warna merah dengan bendera warna putih. Di bagian kedua ditampilkan pesilat secara sendiri-sendiri. Perpindahan transisinya berada di pergantian pesilat satu dengan pesilat yang lain yang ditandai dengan sikap sembah. Ketika pesilat melakukan gerak sembah terakhir ini diteruskan dengan pergantian pesilat di arena pertunjukan. Rangkaian atau kontinuitas gerak merupakan salah satu prinsip yang perlu diperhatikan karena bentuk unsur maupun motif gerak dapat dirasakan sebagai satu pengalaman. Bentuk koreografi bagaikan sebuah kejadian, sehingga ekspresi gerak yang diungkapkan secara abstrak adalah pandangan yang sangat dalam dari seorang penyaji, dalam hal ini pesilat. Oleh sebab itu, kontinuitas sebuah rangkaian gerak yang menarik perhatian para pengamat akan menarik perhatian vitalitas dan intensitas pengalaman, sehingga iring-iringan yang rapi dari rangkaian gerak itu sungguh menjadi mengesankan. Dalam pertunjukan silat pengantin yang di dalamnya terdapat silat bendera dan silat persembahan ini lebih menonjolkan pada pengalaman perorangan. Seorang pesilat sebisa mungkin menunjukkan gerak langkah bunga dengan ketangkasan dan ke- 
ahlian yang dimilikinya. Hasilnya, setiap pesilat memiliki gaya dan karakteristik sendiri-sendiri. Hal ini disebabkan gerak yang disajikan secara seksama, tidak ada gerakan yang dihafalkan atau baku, gerak yang hadir merupakan gerak yang ditampilkan secara spontanitas pada setiap individu pesilatnya. Dalam hal ini, bentuk penyajiannya memiliki struktur rangkaian yang jelas.

Silat Bendera. 1) Langkah awal (tancap bendera). Langkah awal menancapkan bendera merah putih, dengan posisi kedua bendera disilangkan atau tidak dirapatkan, tepatnya tangkai disilangkan. Kemudian, kedua penyaji mengambil posisi mundur menjauh dan berhadapan; 2) Langkah 'bunga'. Diawali salam hormat sikap sembah saling berhadapan kemudian dilanjutkan dengan langkah bunga. Dilakukan dengan berputar beberapa kali dengan saling berhadapan. Langkah bunga ini hasil dari refleksi kedua penyaji dalam berlatih silat sendeng. Gerak yang hadir tidak diharuskan sama atau rampak. Dalam sajiannya, tidak mengutamakan pada kekuatan dan fisik, seperti pencak silat pada umumnya, tapi menggunakan rasa yang hadir pada gerakannya; 3 ) Langkah bendera. Pada langkah bendera, penari memegang bendera yang ditancapkan. Cara menggunakan bendera dengan dipegang tangan kanan. Bergerak dengan 'bunga silat' untuk menggerakkan dan memainkan bendera. Memainkan bendera tidak dianjurkan bersentuhan antara bendera merah dan bendera putih, bergerak berirama dan harmonis dengan berhadapan; 4) Penyatuan bendera. Langkah akhir adalah penyatuan bendera merah dan bendera putih. Hal ini sebagai tanda simbolis yang menggambarkan kedua mempelai pengantin sudah dapat bersatu di dalam bahtera keluarga, dan peristiwa ini dilakukan untuk mengakhiri penampilan silat bendera. Para pesilat menyatukan bendera tersebut, sebagai tanda bahwa penyajian seni silat bendera berakhir.
Silat Persembahan. 1) Salam hormat Raja Sahari. Salam hormat dilakukan dengan cara berdiri atau duduk dengan sikap sembah. Sikap sembah dengan menempelkan kedua telapak tangan di depan wajah pesilat. Langkah selanjutnya dilakukan dengan menghampiri Raja Sahari dengan bersalaman dan kembali ke tengah lagi.

Langkah di atas dilakukan dengan posisi pesilat tetap menghadap ke Raja Sahari; 2) Salam hormat buka silat. Salam hormat buka silat ini meminta ijin kepada Raja Sahari, dan sekaligus sebagai tanda dibukanya seni silat sendeng Bentan Penao. Salam hormat buka silat ini dilakukan dengan sikap sembah. Gerak sembah umumnya dilakukan dengan cara menempelkan kedua telapak tangan di depan dada, buka tangan kanan, buka tangan kiri, dan kembali dirapatkan. Selanjutnya, silat perembahan dimulai; 3) Langkah 'bunga silat'. Langkah bunga adalah langkah atau gerak yang hadir pada gerak seni silat bendera. Langkah tersebut digerakkan secara tiba-tiba oleh karena kebiasaan pesilat dalam mengembangkan langkah silat yang sering dilatih. Gerak yang ditampilkan antara pesilat satu dengan yang lainnya pada umumnya berbeda-beda, hal itu sebagai ciri khas gerak personal. Akan tetapi, karakteristik gerak muncul dengan melihat pijakan gerak baku yang diambil dari pesilatnya, misalnya buka 'bunga silat' dari jurus sembah, puntao, atau cekak. Selama melakukan gerakan, langkah 'bunga silat' ini dilakukan dengan cara menghadap Raja Sahari, dengan mengikuti aturan-aturan selama bergerak. Misalnya, kaki tidak boleh diangkat terlalu tinggi, tangan tidak boleh diangkat terlalu tinggi, tidak boleh membelakangi Raja Sahari, dan selama bergerak harus menghadap Raja Sahari; 4) Salam Penutup. Salam penutup dilakukan saat berakhirnya langkah 'bunga silat', sebagai tanda bahwa silat persembahan untuk personal berakhir. Dilakukan dengan sikap salam hormat buka, 
dan dilanjutkan dengan pesilat yang lainnya, dengan pola-pola yang sama.

\section{Analisis Teknik Gerak}

Dalam hal teknik gerak, setiap penari harus menguasai hal tersebut. Persoalan teknik tidak semata-mata teoritis, seorang penari maupun koreografer harus mempunyai bakat, keterampilan, dan kepekaan untuk merasakan masalah bentuk kompoisisi tari, seperti gerak ruang dan waktu (Hadi, 2007: 29-33).

Teknik kaki terlihat pada langkah bunga, antara lain buka dan tutup, melangkah ke kanan dan kiri, level rendah (duduk), sedang (buka kuda-kuda), dan tinggi (biasa). Teknik kaki ditampilkan tergantung. Pesilatnya ingin mengambil langkah apa dan tentu akan berpengaruh pada penggunaan langkah kaki yang dominan, misalnya mengambil langkah sembah, teknik langkah kaki lebih sering ke bawah atau merendah dan duduk. Langkah cekak dan puntao, langkah buka kaki akan sering membuka kudakuda. Tangan pesilat pada umumnya selalu kuat atau bertenaga. Tampilan teknik pada tangan biasanya mengikuti langkah/ jurus yang digunakan oleh pesilatnya. Antara lain, langkah sembah, teknik yang digunakan, yaitu sikap jari-jari tangan selalu membuka lurus dan mengolah pergelangan tangan, walaupun bergerak ke kanan atau ke kiri. Walaupun sering membuka jari tangan dan mengolah pergelangan tangan, sesekali mengepal dan meninju dengan tenaga yang besar. Kepala pesilat umumnya mengarah ke depan dengan kepala sedikit menengadah ke atas dan tatapan tajam. Hal ini dilakukan agar terlihat gagah dan ksatria. Biasanya, kepala dan pandangan mata selalu melihat atau fokus pada raja sehari, walaupun kaki melangkah ke kanan dan ke kiri. Sikap badan pesilat saat penyajian berlangsung selalu tegak dan sedikit condong ke depan. Saat bergerak penggunaan torso yang paling berperan. Untuk meng- gerakkan badan ke samping kanan dan kiri, badan condong merendah ke depan, dan tegap lurus ke atas.

\section{Analisis Gaya Gerak}

Pengertian gaya selalu melekat pada sebuah tarian atau koreografi yang sedang dipertunjukkan. Gaya atau style dalam pemahaman ini lebih mengarah pada bentuk ciri khas atau corak yang terdapat pada gaya gerakan (Hadi, 2013: 33-35).

Ciri khas gaya juga berkaitan dengan latar belakang budayanya. Dalam hal ini, seni silat bendera mengandung gaya Melayu. Gaya silat tradisi Melayu pada umumnya mempunyai ciri khas pada bentuk langkah kaki. Gaya berbusana tercermin dalam tradisi Melayu. Gaya pada instrumen musik yang digunakan juga sangat kental dengan tradisi Melayu. Gaya gerak seni silat Melayu ini, seperti gaya gerak silat pada umumnya, seperti dominan gerak pada sikap bentuk kuda-kuda, gerak lebih banyak mengeksplor gerakan tangan yang menonjolkan pada kekuatan.

\section{Analisis Jumlah Pesilat}

Koreografi kelompok adalah koreografi yang dilakukan oleh dua orang atau lebih. Menurut Hadi, komposisi kelompok yang terdiri dari empat penari, dan lebih dari empat penari, dapat dikatakan komposisi dalam kelompok besar, karena jumlah empat penari dapat dibagi lagi menjadi dua komposisi kelompok kecil yang terdiri masing-masing dua penari atau duet (Hadi, 2007: 35-51). Penyajian seni silat Melayu terdiri dari dua orang pesilat bendera dan pesilat persembahan. Tidak ada aturan baku dalam jumlah personil yang dipentaskan, akan tetapi dalam penyajiannya dilakukan secara bergantian. Hal ini berarti ditampilkan tunggal atau perorangan, dan dilakukan secara bergantian.

Pemilihan penyaji dalam seni silat bendera harus memiliki kriteria khusus. Anta- 
ra lain, harus memiliki keahlian khusus di bidang silat sendeng Bentan Penao di bawah naungan perguruan Kiambang Putih. Hal ini diharapkan penguasaan keahlian di bidang silat sendeng dapat teruji. Sehingga dalam mengembangkan langkah bunga seni silat bendera ini dapat ditampilkan secara maksimal.

Sajian silat bendera bagian pertama ditampilan oleh dua orang pesilat dengan berhadap-hadapan. Dalam pola penyajiannya terdiri dari dua pusat perhatian (focus on two points) dan satu fokus perhatian (focus on one point). Bagian kedua ditampilkan oleh satu penyaji yang dilakukan secara bergantian dengan pesilat yang lainnya. Sedangkan dalam bentuk penyajian, silat persembahan terdiri dari satu orang pesilat secara bergantian. Pemahaman analisis tekstualnya lebih sederhana bila dibandingkan dengan koreografi kelompok. Kemampuan kreativitas berimprovisasi yang dituntut sewaktu-waktu dapat memperlihatkan kreativitas secara spontan di atas pentas. Kemampuan dasar pesilat ini harus memiliki dasar yang kuat. Konsep penguasaan penari tunggal secara langsung dapat diidentifikasi bahwa bentuk penyajiannya adalah menampilkan konsep focus on one point, yang fokus perhatiannya adalah satu fokus. Secara teknis, dapat dilakukan secara bergantian.

\section{Analisis Jenis Kelamin dan Postur Tubuh}

Pada seni silat bendera, analisis jenis kelamin dan postur tubuh lebih bersifat non-literal. Para pesilat yang hadir tidak dibakukan dengan melihat fisik, akan tetapi hanya melihat dari latar belakang pengalaman atau skill individu. Yaitu, harus memiliki pengalaman dalam mempelajari silat sendeng Bentan Penao terlebih dahulu. Dalam pemilihan jenis kelamin, pesilat tidak ada pembakuan harus laki-laki atau perempuan saja, bisa laki-laki atau pun perempuan. Asal memiliki pengetahuan ilmu silat sendeng Bentan Penaoo dapat menyajian seni silat bendera sehingga gerakannya tampak berkualitas dan memiliki karakteristik tersendiri.

\section{Analisis Struktur Ruangan}

Seorang pesilat dengan keterampilan geraknya dapat membuat ilusi-ilusi, sehingga ruang menjadi fleksibel. Ruang pementasan atau tempat penyajian seni silat bendera ditempatkan pada ruang terbuka atau out door. Secara visual gerak tampak jelas terlihat dari berbagai sisi oleh penonton. Di sini, penonton benar-benar melihat dan menyadari kehadiran aspek-aspek ruang karena gerakan tubuh secara keseluruhan, sehingga merupakan komponen visual gerak yang kuat.

\section{Analisis Struktur Waktu}

Struktur waktu dalam gerak seni silat bendera cenderung monoton atau sama. Gerak-gerak yang dihadirkan lebih menekankan pada hentakan di setiap akhir geraknya. Hal ini dilakukan sebagai gambaran bahwa pertunjukan seni silat Melayu memiliki karakteristik pesilat atau kesatria. Gerak-geraknya tegas, kokoh, dan menghentak. Pesilat sebagai penyaji dibebaskan mengambil lion atau jurus sebagai langkah bunganya. Setiap lion atau jurus masing-masing memiliki karakteristik yang berbeda.

Jurus sembah pada geraknya memiliki ritme dan tempo cenderung lambat dan mengalun. Hanya pada saat akhir di setiap gerak saja yang sering terlihat adanya penekanan maupun penegasan tenaga yang lebih besar. Hal ini karena struktur ruangnya meluas dan hanya sekali-kali pada akhir geraknya cepat serta cenderung ruangnya mengecil. Sedangkan pada jurus kuntau sebaliknya, memiliki karakteristik gerak lebih dominan cepat, tegas, patah-patah dan ekspresif. Hal ini disebabkan bahwa gerak kuntao sendiri memiliki struktur ruang lebih kecil-kecil, tegas, lebih berotot yang menampakan tenaga dari dalam yang dikeluarkan. Berbeda lagi dengan jurus cekak yang 


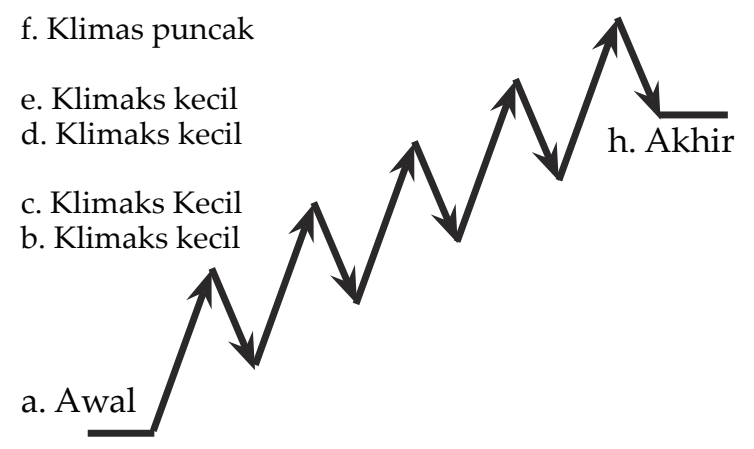

Gambar 4. Skema "kerucut berganda" Tangga dramatik pertunjukan silat pengantin, Bentan Penao, Kepulauan Riau

lebih berada di tengah-tengah antara jurus sembah dan cekak. Jurus cekak lebih memiliki vareasi gerak dimana geraknya terkadang cepat dan terkadang lambat. Tempo lambat saat membuka ruang yang lebih besar dan luas, sedangkan tempo cepat tampak menutup ruang, cepat dan tekanan tenaganya lebih menonjol. Jurus kuntao biasanya mengambil tenaga yang digunakan hasil dari tenaga lawan. Selanjutnya, jurus pukul umumnya lebih fleksibel, digunakan oleh pesilat. Jurus pukul ini cenderung lebih mudah masuk ke jurus sembah, kuntao, maupun cekak.

\section{Analisis Struktur Dramatik}

Dalam analisis struktur dramatik sajian pertunjukan seni tradisi silat pengantin terdapat beberapa klimaks kecil, karena ditampilkan oleh para pesilat secara bergantian. Namun demikian, klimaks-klimaks kecil tersebut semakin lama semakin tinggi dan pada akhinya membentuk titik klimaks yang besar. Akibatnya, penyajian seni silat pengantin ini menampilkan struktur dramatik titik klimaks kerucut ganda. Lebih jelasnya, terlihat pada gambar desain skema "kerucut berganda" pada gambar 4 .

\section{Analisis Tata Teknik Pentas}

Analisis tata teknik pentas merupakan salah satu bagian dari analisis koreografis yang mendukung sebuah garapan atau pertunjukan tari. Analisis tata teknik pentas meliputi tata cahaya, tata rias dan busana, serta properti atau perlengkapan lainnya
(Hadi, 2007: 29-33). Pertunjukan silat pengantin sangatlah sederhana, karena masuk di dalam prosesi pernikahan adat Melayu. Dalam bentuk penyajiannya lebih fleksibel dan ditempatkan di depan pintu masuk menuju ke pelaminan pengantin.

\section{Musik Pengiring}

Musik pengiring pada mulanya digunakan untuk mengiringi upacara adat atau tari yang berfungsi sebagian sarana adat. Penyajian musiknya pada umumnya bersifat monoton dan belum ada suatu patokan yang menjadi pedoman penari (secara naluriah saja). Tarian dan musik menjadi dua bentuk kesenian yang masing-masing saling membutuhkan. Hubungan tersebut dilakukan berdasarkan kebutuhan ritme dan ekspresi di antara musik dan tari, misalnya tari persembahan, tari Zapin penyengat, ataupun silat pengantin dalam upacara pernikahan adat Melayu.

Musik untuk mengiringi silat Pengantin Bentan Penao dan silat pada umumnya, terdapat kesamaan dengan daerah lain di wilayah Kepulauan Riau yang masih digunakan alat musik tradisional yang sederhana. Alat musik pengiring silat pengantin yang umum dipakai adalah sebagai berikut. (1) Gendang silat merupakan alat musik tradisional yang digunakan sebagai pengatur irama, sebagai penentu dan pengubah gerak. Gendang silat terbuat dari kayu, rotan, dan kulit binatang. Gendang silat berupa gendang berkepala ganda. Pada saat dimainkan biasanya dilakukan dengan cara digendong dengan diikat tali yang dikaitkan di bahu pemusiknya. Pertunjukannya biasanya dilakukan dengan cara berdiri dan bisa juga dimainkan dengan posisi duduk, tergantung pada kekuatan penabuh gendangnya. Jumlah kendang yang dimainkan biasanya minimum dua buah kendang silat. Ditampilkan dengan pola pukul saling mengisi atau imbal-imbalan.

(2) Gong adalah alat musik pukul yang umum ditemui di banyak provinsi Indone- 
sia. Alat musik yang dibuat dari perunggu atau logam lainnya ini merupakan alat musik (waditra) berbentuk bundar dan besar seperti kuali. Sebagai waditra berpenclon yang sangat besar, gong mempunyai garis tengah $69 \mathrm{~cm} \mathrm{~s} / \mathrm{d} 105 \mathrm{~cm}$, umumnya saat memainkan silat pengantin hanya berjumlah satu buah. Pada saat dimainkan biasanya hanya ditenteng dengan tangan kiri dan tangan kanan memegang pemukulnya, dan dimainkan dengan cara berdiri.

\section{Tata Rias dan Busana}

Tampilan tata rias dan busana sangatlah penting. Tata rias dan busana harus menopang tarian, sehingga secara konseptual perlu dijelaskan alasan penggunaan atau pemilihan rias dan busana dalam catatan atau skrip tarinya (Hawkins, 2003). Namun, dalam kesenian tradisi, peranan tata rias tidaklah menjadi perwujudan yang paling utama. Apalagi dalam pertunjukan seni tradisi silat Melayu, konsep tata rias tidaklah begitu diutamakan karena konsep yang ditonjolkan adalah konsep natural atau apa adanya. Hal ini lebih menonjolkan fungsinya, yaitu seni silat atau langkah bunga yang diproyeksikan sebagai pesilat dalam pertunjukan di dalam seni silat Melayu (silat persembahan ataupun silat pengantin).

Tata busana pada pertunjukan seni tradisi Melayu memakai kostum Melayu yang mengidentifikasi bahwa tarian ini merupakan tari tradisional Melayu. Hal itu antara lain adalah memakai baju kurung cekak musang atau baju kurung teluk belanga, kain samping bermotif serupa dengan celana dan baju, dan ikat kepala menggunakan tanjak.

\section{Tata Rupa Pentas}

Pertunjukan silat pengantin merupakan bagian satu kesatuan dari prosesi pernikahan, sehingga tempat pementasannya biasanya pada acara pernikahan, tepatnya di pelataran, di depan gerbang masuk rumah pengantin perempuan, yang berdekatan dengan tempat duduk pelaminan. Tempat pementasan di ruang yang luas dan apa adanya atau tempat pertunjukan tidak menggunakan desain panggung atau sering disebut dengan setting. Dengan demikian, penampilan dilakukan di tempat apa adanya dan terkesan merakyat serta melekat dengan prosesi pernikahannya.

Tata cahaya atau lighting yang ditampilkan dalam pertunjukan silat pengantin ini adalah menggunakan konsep tata cahaya matahari. Apabila tempat pementasannya di dalam gedung juga menampilkan konsep tata cahaya secara natural. Hal ini memberi kesan apa adanya membaur dan menyatu dalam prosesi adat pernikahan. Pertunjukan biasanya dilakukan siang hari, tepatnya sebelum waktu zuhur ataupun sesudah waktu zuhur. Oleh karena itu, tata cahaya seperti lampu secara tidak langsung tidak berperan dalam pencahayaan pertunjukan silat pengantin ini.

Properti yang digunakan adalah bendera berwarna merah dan putih. Yang dipegang dan dieksplor oleh kedua penari, di antaranya adalah satu orang pesilat atau penyaji yang mengeksplor bendera merah dan satu pesilat mengeksplor bendera putih. Properti bendera ini punya makna, yakni warna merah menggambarkan darah merah, dan warna putih merupakan simbol darah putih atau tulang sumsum. Pada akhir pertunjukan, bendera ini ditandai dengan menyatunya kedua bendera. Hal ini mengggambarkan menyatunya kedua mempelai dalam sebuah perkawinan.

\section{SIMPULAN}

Silat pengantin di Bentan Penao disebut juga dengan istilah silat bendera. Bentuk penyajiannya sebagai penghormatan dan pengawalan bertemunya antara mempelai laki-laki dan mempelai wanita, yang disimbolkan dengan bendera berwarna merah dan putih. Seni silat Melayu di dalam adat perkawinan wilayah Bentan Penao, dinamakan "silat bendera." Simbol bendera berwarna merah dan putih memiliki makna untuk mempersatukan dua insan manusia ke dalam bahtera keluarga. Bendera merah 
dimaknai sebagai darah merah yang dalam hal ini dari mempelai wanita, dan simbol bendera putih dimaknai sebagai darah putih yang dalam hal ini dari mempelai lakilaki. Dengan demikian, memainkan bendera merah dan putih ini sebagai penggambaran kehidupan dua insan manusia yang saling berinteraksi dalam ikatan tali suci dalam satu kehidupan yang saling berkaitan.

Dalam pertunjukan silat pengantin yang di dalamnya terdapat silat bendera dan silat persembahan ini lebih menonjolkan pada pengalaman perorangan, seorang pesilat sebisa mungkin menunjukkan gerak langkah bunga dengan ketangkasan dan keahlian yang dimilikinya. Hasilnya, setiap pesilat memiliki gaya dan karakteristik sendirisendiri. Hal ini disebabkan karena gerak yang disajikan secara saksama itu tidak ada gerakan yang dihafalkan atau baku. Gerak yang hadir merupakan gerak yang ditampilkan secara spontanitas oleh setiap individu pesilatnya. Hanya saja, dalam bentuk penyajiannya memiliki struktur rangkaian yang jelas. Gerak yang hadir dalam penyajian seni silat bendera ini mengembangkan dari langkah silat sendeng sebagai pijakan dasarnya. Antara lain, langkah empat arah mata angina. Selanjutnya, dikembangkan lagi menjadi delapan langkah penjuru dan menjadi titik yang kesembilannya adalah diri pesilatnya.

Penelitian ini akan sangat berguna bagi masyarakat luas, khususnya masyarakat Melayu di wilayah Kepulauan Riau sebagai sumber acuan dan ruang apresiasi praktik ataupun teori di bidang ilmu pengetahuan budaya bagi generasi muda saat ini dan masa yang akan datang.

\section{Ucapan Terima Kasih}

Penelitian ini di danai oleh Hibah Internal Universitas Universal (011/IMT/UVERS/1/2017). Penulis menyampaikan terima kasih kepada:
Rektor Universitas Universal, Dr. Kisdarjono, Wakil Rektor Universitas Universal, Dr. Aswandy, LPPM Universitas Universal. Terima kasih juga pimpinan perguruan Kiambang Putih, pencak silat sendeng Bentan Penaoo, Kepulauan Riau, Ayah Raja Timat.

Pimpinan seni silat melayu Empat Sahabat, di Tanjung Uma,Uwak Raja Ajbi, dan tim pelaksana yang membantu proses penelitian di lapangan, yaitu bang Redha dan bang Irwan sebagai pendokumentasi.

Pengurus Yayasan Pancaran Maitri, Batam yang sudah memberikan pinjaman hibah penelitian di Universitas Universal.

\section{Daftar Pustaka}

Gazalba, S. (1967). Pengantar Kebudayaan Sebagai Ilmu. Jakarta: Pustaka Antara.

Hadi , Y. S. (2016). Koreografi Bentuk - Teknik - Isi. Yogyakarta: Cipta Media.

. (2005). Sosiologi Tari. Yogyakarta: Pustaka.

(2007). Kajian Teks dan Konteks. Yogyakarta: Pustaka.

Hersapandi. (2017). Sendratari Rara Jonggrang dalam Perspektif Koreografis dan Pariwisata." Panggung, 27 (2) Juni, 177-186.

Kadir, N., dkk. (2012). Adat Istiadat Melayu Batam. Batam: Lembaga Adat.

Murgiyanto, S. (2004). Tradisi dan Inovasi, Beberapa Masalah Tari di Indonesia. Jakarta: Wedatama Widya Sastra.

Restela, R. dan T. Narawati. (2017). “Tari Rampoe sebagai Cerminan Karakteristik Masyarakat Aceh. Panggung, 27 (2), 187-200.

Takari. (2014). Ronggeng dan Serampang Dua Belas, Dalam Kajian Ilmu-Ilmu Seni. Medan: USU Press.

Hawkins, Alma M. (1990). Creating through Dance. Diterjemahkan oleh. Y. Sumandiyo Hadi. 2003. Mencipta Lewat Tari. Yogyakarta: ISI Yogyakarta. 